\title{
Synthesis and Characterization of $\left[2-\mathrm{CH}_{3} \mathrm{CH}_{2} \mathrm{C}_{6} \mathrm{H}_{4} \mathrm{NH}_{3}\right]_{6} \mathrm{P}_{6} \mathrm{O}_{18}-4 \mathrm{H}_{2} \mathrm{O}$
}

\author{
Houda Marouani, ${ }^{1}$ Salem Slayyem Al-Deyab, ${ }^{2}$ and Mohamed Rzaigui ${ }^{1}$ \\ ${ }^{1}$ Laboratoire de Chimie des Matériaux, Faculté des Sciences de Bizerte, 7021 Zarzouna, Tunisia \\ ${ }^{2}$ Chemistry Department, College of Science, King Saud University, P.O. Box 2455, Riyadh 11451, Saudi Arabia
}

Correspondence should be addressed to Houda Marouani, houda_marouani@voila.fr

Received 27 March 2011; Accepted 29 May 2011

Academic Editors: R. A. Dunlap and I.-S. Kim

Copyright (C) 2011 Houda Marouani et al. This is an open access article distributed under the Creative Commons Attribution License, which permits unrestricted use, distribution, and reproduction in any medium, provided the original work is properly cited.

\begin{abstract}
Single crystals of [2- $\left.\mathrm{CH}_{3} \mathrm{CH}_{2} \mathrm{C}_{6} \mathrm{H}_{4} \mathrm{NH}_{3}\right]_{6} \mathrm{P}_{6} \mathrm{O}_{18} \cdot 4 \mathrm{H}_{2} \mathrm{O}$ are synthesized in aqueous solution by the interaction of cyclohexaphosphoric acid and 2-ethylaniline. This compound crystallizes in the monoclinic system with $\mathrm{P} 2{ }_{1} / \mathrm{c}$ space group the unit cell dimensions are: $a=16.220(4) \AA, b=10.220(5) \AA, c=20.328(4) \AA, \beta=113.24(3)^{\circ}, Z=2$, and $V=3096.5(18) \AA^{3}$. The atomic arrangement can be described by layers formed by cyclohexaphosphate anions $\mathrm{P}_{6} \mathrm{O}_{18}^{6-}$ and water molecules connected by hydrogen bonds $\mathrm{O}-\mathrm{H} \cdots \mathrm{O}$. These inorganic layers are developed around bc planes at $x=1 / 2$ and are interconnected by the $\mathrm{H}$-bonds created by ammonium groups of organic cations. All the hydrogen bonds, the van der Waals contacts and electrostatic interactions between the different entities give rise to a three-dimensional network in the structure and add stability to this compound. The thermal behaviour and the IR spectroscopic studies of this new cyclohexaphosphate are discussed.
\end{abstract}

\section{Introduction}

Organic-inorganic hybrid compounds have been of great interest in recent years due to their unique opportunity to combine the remarkable features of organic materials with those of inorganic compounds. In particular, hybrid materials based on the phosphates have attracted much attention due to their technological interest in several areas such as biomolecular sciences, catalysts, and optics [1-3].

The cohesion forces in these hybrid compounds are dominated by electrostatic interactions, van der Waals contacts and hydrogen bond $(\mathrm{O}-\mathrm{H} \cdots \mathrm{O}, \mathrm{N}-\mathrm{H} \cdots \mathrm{O}$ and $\mathrm{C}-$ $\mathrm{H} \cdot \cdots \mathrm{O}$ ). In order to enrich these materials and to investigate the influence of hydrogen bonds on the chemical and structural features, we report here the synthesis, crystal structure, thermal analysis, and IR spectroscopy of a new organic cyclohexaphosphate, [2- $\left.\mathrm{CH}_{3} \mathrm{CH}_{2} \mathrm{C}_{6} \mathrm{H}_{4} \mathrm{NH}_{3}\right]_{6} \mathrm{P}_{6} \mathrm{O}_{18} \cdot 4 \mathrm{H}_{2} \mathrm{O}$.

\section{Experimental Section}

2.1. Synthesis. The title compound was prepared by an acid/ base reaction in two steps. In the first one, we pre- pared $\mathrm{Li}_{6} \mathrm{P}_{6} \mathrm{O}_{18} \cdot 6 \mathrm{H}_{2} \mathrm{O}$ according to the process described by Schülke and Kayser [4]. From this lithium salt, we prepared an aqueous solution of cyclohexaphosphate acid $\mathrm{H}_{6} \mathrm{P}_{6} \mathrm{O}_{18}$ by passing a solution of $\mathrm{Li}_{6} \mathrm{P}_{6} \mathrm{O}_{18} \cdot 6 \mathrm{H}_{2} \mathrm{O}(1 \mathrm{~g}$, $2.3 \mathrm{mmol})$ through an ion-exchange resin in its $\mathrm{H}$-state (Amberlite IR 120). In the second step, at $20 \mathrm{~mL}$ of the aqueous solution of $\mathrm{H}_{6} \mathrm{P}_{6} \mathrm{O}_{18}$ freshly prepared, we add drop by drop a solution of 2-ethylaniline $(1.70 \mathrm{~mL}$, $13.8 \mathrm{mmol}, d=0.983$ ) in $20 \mathrm{~mL}$ of ethanol under continuous stirring. Schematically, the reaction can be written as follows:

$$
\begin{gathered}
\mathrm{H}_{6} \mathrm{P}_{6} \mathrm{O}_{18}+6\left(2-\mathrm{CH}_{3} \mathrm{CH}_{2} \mathrm{C}_{6} \mathrm{H}_{4} \mathrm{NH}_{2}\right)+4 \mathrm{H}_{2} \mathrm{O} \\
\longrightarrow\left[2-\mathrm{CH}_{3} \mathrm{CH}_{2} \mathrm{C}_{6} \mathrm{H}_{4} \mathrm{NH}_{3}\right]_{6} \mathrm{P}_{6} \mathrm{O}_{18} \cdot 4 \mathrm{H}_{2} \mathrm{O} .
\end{gathered}
$$

In order to avoid the hydrolysis of the ring anion, the above reaction is performed at room temperature. The obtained solution was then slowly evaporated until the formation of colorless prisms of $\left[2-\mathrm{CH}_{3} \mathrm{CH}_{2} \mathrm{C}_{6} \mathrm{H}_{4}\right.$ $\left.\mathrm{NH}_{3}\right]_{6} \mathrm{P}_{6} \mathrm{O}_{18} \cdot 4 \mathrm{H}_{2} \mathrm{O}(m=1.9 \mathrm{~g}$, yield $=65 \%)$. The title compound was stable for months under normal conditions of temperature and relative humidity. 
TABLE 1: Summary of crystallographic data of $\left[2-\mathrm{CH}_{3} \mathrm{CH}_{2} \mathrm{C}_{6} \mathrm{H}_{4}\right.$ $\left.\mathrm{NH}_{3}\right]_{6} \mathrm{P}_{6} \mathrm{O}_{18} \cdot 4 \mathrm{H}_{2} \mathrm{O}$.

\begin{tabular}{ll}
\hline Chemical formula & {$\left[2-\mathrm{CH}_{3} \mathrm{CH}_{2} \mathrm{C}_{6} \mathrm{H}_{4} \mathrm{NH}_{3}\right]_{6} \mathrm{P}_{6} \mathrm{O}_{18} \cdot 4 \mathrm{H}_{2} \mathrm{O}$} \\
Molecular weight & 1279.00 \\
Temperature, $\mathrm{K}$ & 293 \\
Wavelength, $\AA$ & 0.71073 \\
Crystal system & monoclinic \\
Space group, $Z$ & $\mathrm{P} 2{ }_{1} / \mathrm{c}, 2$ \\
$a, b, c, \AA$ & $16.220(4), 10.220(5), 20.328(4)$ \\
$\beta$, deg & $113.24(3)$ \\
$V, \AA^{3}$ & $3096.5(18)$ \\
$\rho_{\text {cal. }}$, g/cm & \\
$\mu$, mm & -1 \\
$F(000)$ & 1.372 \\
Crystal sizes, mm & 0.252 \\
Crystal shape & 1352 \\
$\theta$ range for data & $0.30 \times 0.25 \times 0.10$ \\
collection, deg & Prism \\
Independent reflections & $8.21,29.97$ \\
Reflections/restraints/ & $8404 / 63 / 315$ \\
parameters & \\
$R\left[F^{2}>2 \sigma\left(F^{2}\right)\right]$ & 0.072 \\
$w R\left(F^{2}\right)$ & 0.157 \\
Goodness-of-fit & 0.995 \\
Maximum and minimum & \\
residual electron density, & 0.85 and -0.42 \\
e/ $\AA^{3}$ & \\
\hline
\end{tabular}

2.2. X-Ray Diffraction. The intensity data were collected at room temperature using an Enraf-Nonius CAD4 diffractometer with MoK $\bar{\alpha}$ radiation. The cell parameters were determined from a least square refinement of 25 reflections. Two-standard reflections were periodically measured for every $120 \mathrm{~min}$ during data collection. Unique reflections (8617) were measured of which only 3940 had $\mathrm{I} \geq 2 \sigma(\mathrm{I})$ and were used for structure determination and refinement. The structure was solved by direct method using the program SHELXS-97 [5] in the WinGX package [6] and refined by full-matrix least-squares method with the program SHELXL-97 [5]. All nonhydrogen atoms were refined isotropically and then anisotropically by full matrix least-square method. All water $\mathrm{H}$ atoms were first located in a difference Fourier map and then refined with distance restraints of $\mathrm{O}-\mathrm{H}=0.85(1) \AA$ and $\mathrm{H} \cdots \mathrm{H}=1.44(2) \AA$. The remaining hydrogen atoms were placed geometrically and treated as riding. The parameters used for the X-ray diffraction data collection as well as the strategy used for the crystal structure determination and its final results are reported in Table 1. The main bond distances and bond angles for the title compound are provided in Table 2 and the main geometrical features of the hydrogen-bond scheme in Table 3.

Crystallographic data (CIF) for the structure reported in this paper have been deposited in the Cambridge Crystallographic Data centre as supplementary materials No
TABle 2: Main interatomic distances $(\AA)$ and angles $\left(^{\circ}\right)$ in the $\mathrm{P}_{6} \mathrm{O}_{18}$ ring of [2- $\left.\mathrm{CH}_{3} \mathrm{CH}_{2} \mathrm{C}_{6} \mathrm{H}_{4} \mathrm{NH}_{3}\right]_{6} \mathrm{P}_{6} \mathrm{O}_{18} \cdot 4 \mathrm{H}_{2} \mathrm{O}$.

\begin{tabular}{|c|c|c|c|c|}
\hline $\begin{array}{l}\text { Tetrahedron } \\
\mathrm{P}(1) \mathrm{O}_{4}\end{array}$ & & & & \\
\hline P1 & $\mathrm{O} 1$ & $\mathrm{O} 2$ & $\mathrm{O} 3$ & O9 \\
\hline $\mathrm{O} 1$ & $1.480(3)$ & $120.34(15)$ & $109.09(15)$ & $104.95(16)$ \\
\hline $\mathrm{O} 2$ & $2.557(4)$ & $1.467(3)$ & $107.01(15)$ & $111.82(15)$ \\
\hline $\mathrm{O} 3$ & $2.505(4)$ & $2.462(4)$ & $1.594(3)$ & $102.15(16)$ \\
\hline O9 & $2.449(5)$ & $2.546(4)$ & $2.490(4)$ & $1.606(3)$ \\
\hline $\begin{array}{l}\text { Tetrahedron } \\
\mathrm{P}(2) \mathrm{O}_{4}\end{array}$ & & & & \\
\hline P2 & $\mathrm{O} 3$ & O4 & $\mathrm{O} 5$ & O6 \\
\hline $\mathrm{O} 3$ & $1.593(3)$ & $106.40(16)$ & $108.37(16)$ & $102.24(14)$ \\
\hline O4 & $2.465(4)$ & $1.484(3)$ & $119.48(16)$ & $107.88(15)$ \\
\hline O5 & $2.484(4)$ & $2.550(5)$ & $1.469(3)$ & $111.01(16)$ \\
\hline O6 & $2.494(4)$ & $2.502(4)$ & $2.539(4)$ & $1.610(3)$ \\
\hline $\begin{array}{l}\text { Tetrahedron } \\
\mathrm{P}(3) \mathrm{O}_{4}\end{array}$ & & & & \\
\hline P3 & O6 & O7 & $\mathrm{O} 8$ & O9 \\
\hline O6 & $1.603(3)$ & $104.99(15)$ & $111.44(15)$ & $99.56(15)$ \\
\hline O7 & $2.456(3)$ & $1.491(3)$ & $120.07(15)$ & $109.87(15)$ \\
\hline O8 & $2.539(4)$ & $2.563(4)$ & $1.468(3)$ & $108.94(16)$ \\
\hline O9 & $2.447(5)$ & $2.532(4)$ & $2.500(4)$ & $1.602(3)$ \\
\hline P1-P2 & $2.9826(16)$ & P1-P3 & $2.9102(14)$ & $\begin{array}{c}\text { P2-P3 } \\
2.9285(14)\end{array}$ \\
\hline P3-P2-P1 & $100.65(1)$ & $\mathrm{P} 1-\mathrm{O}$ & $3-\mathrm{P} 2$ & $138.67(19)$ \\
\hline $\mathrm{P} 2-\mathrm{P} 1-\mathrm{P} 3$ & $100.04(1)$ & $\mathrm{P} 1-\mathrm{O}$ & $99-P 3$ & $130.21(17)$ \\
\hline P2-P3-P1 & $115.55(1)$ & $\mathrm{P} 3-\mathrm{O}$ & 6-P2 & $131.40(20)$ \\
\hline
\end{tabular}

Estimated standard deviations are given in parentheses.

Table 3: Bond lengths $(\AA)$ and angles $\left(^{\circ}\right)$ in the hydrogen-bonding scheme.

\begin{tabular}{|c|c|c|c|c|}
\hline $\mathrm{D}-\mathrm{H} \cdots \mathrm{A}$ & $\mathrm{D}-\mathrm{H}$ & $\mathrm{H} \cdots \mathrm{A}$ & $\mathrm{D} \cdots \mathrm{A}$ & $\mathrm{D}-\mathrm{H} \cdots \mathrm{A}$ \\
\hline O10-H110 $\cdots$ O1 & $0.847(10)$ & $1.99(2)$ & $2.800(4)$ & $158(5)$ \\
\hline $\mathrm{O} 10-\mathrm{H} 210 \cdots \mathrm{O} 4$ & $0.844(10)$ & $1.93(2)$ & $2.724(4)$ & $156(5)$ \\
\hline $\mathrm{O} 11-\mathrm{H} 111 \cdots \mathrm{O} 2$ & $0.853(10)$ & $2.409(17)$ & $3.255(5)$ & $171(8)$ \\
\hline $\mathrm{O} 11-\mathrm{H} 211 \cdots \mathrm{O} 7$ & $0.858(10)$ & $1.949(11)$ & $2.807(4)$ & $178(5)$ \\
\hline $\mathrm{N} 1-\mathrm{H} 1 \mathrm{~A} \cdots \mathrm{O} 5$ & 0.89 & 1.85 & $2.735(4)$ & 170.5 \\
\hline N1-H1B $\cdots$ O7 & 0.89 & 1.93 & $2.800(4)$ & 165.7 \\
\hline $\mathrm{N} 1-\mathrm{H} 1 \mathrm{C} \cdots \mathrm{O} 1$ & 0.89 & 1.97 & $2.854(4)$ & 169.9 \\
\hline $\mathrm{N} 2-\mathrm{H} 2 \mathrm{~A} \cdots \mathrm{O} 4$ & 0.89 & 1.90 & $2.781(4)$ & 171.1 \\
\hline $\mathrm{N} 2 \mathrm{H} 2 \mathrm{~B} \cdots \mathrm{O} 10$ & 0.89 & 1.98 & $2.854(5)$ & 166.4 \\
\hline N2-H2C $\cdots$ O11 & 0.89 & 1.99 & $2.808(5)$ & 151.7 \\
\hline N3-H3A $\cdots$ O10 & 0.89 & 2.06 & $2.903(5)$ & 158.4 \\
\hline $\mathrm{N} 3-\mathrm{H} 3 \mathrm{~B} \cdots \mathrm{O} 2$ & 0.89 & 1.92 & $2.719(4)$ & 148.8 \\
\hline $\mathrm{N} 3-\mathrm{H} 3 \mathrm{C} \cdot \mathrm{O} 8$ & 0.89 & 1.89 & $2.737(4)$ & 159.7 \\
\hline $\mathrm{C} 14-\mathrm{H} 14 \cdots \mathrm{O} 1$ & 0.93 & 2.55 & $3.281(6)$ & 135.2 \\
\hline $\mathrm{C} 21-\mathrm{H} 21 \cdots \mathrm{O} 3$ & 0.93 & 2.50 & $3.422(8)$ & 168.9 \\
\hline
\end{tabular}

Estimated standard deviations are given in parentheses.

CCDC 798115. Copies of the data can be obtained, free of charge, on application to the CCDC, 12 Union Road, 


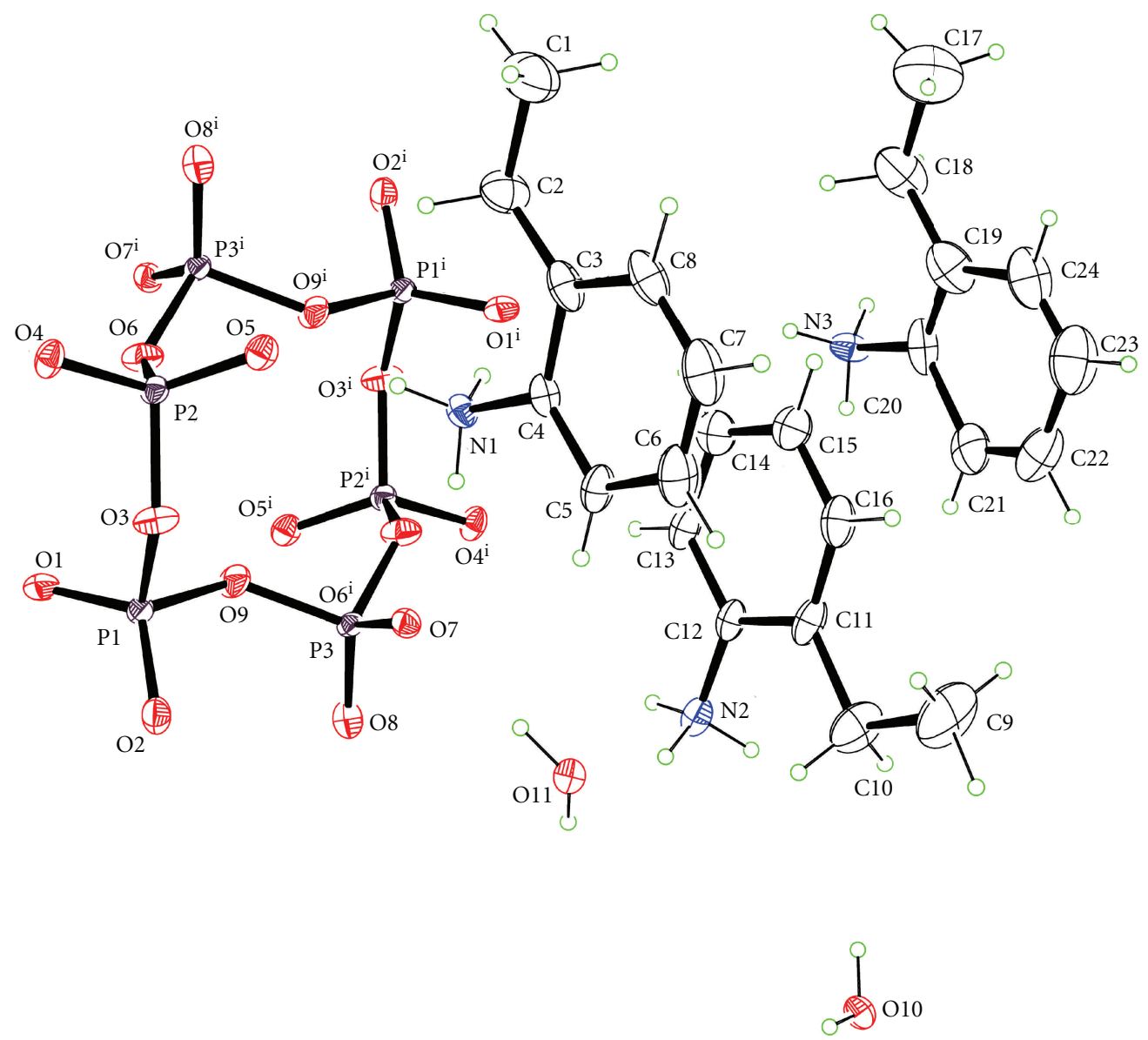

FIGURE 1: ORTEP drawing of $\mathrm{P}_{6} \mathrm{O}_{18}^{6-}$ anion and the crystallographical independent components of the molecular structure (30\% thermal ellipsoids). Symmetry code: i: $1-x, 2-y, 1-z$.

Cambridge CB12EZ, UK (Fax: ++44(1223) 336-033; email: deposit@ccdc.cam.ac.uk).

2.3. Thermal Analysis. Thermal analysis was performed using the "multimodule 92 Setaram analyser" operating from room temperature up to $673 \mathrm{~K}$ at an average heating rate of $5 \mathrm{~K} \mathrm{~min}^{-1}$.

2.4. Infrared Spectroscopy. IR spectrum is recorded in the range $4000-400 \mathrm{~cm}^{-1}$ with a "PerkinElmer FTIR" spectrometer using a sample dispersed in spectroscopically pure $\mathrm{KBr}$ pellet.

\section{Results and Discussion}

3.1. Crystal Structure. The title compound (Figure 1) is a hybrid of organic and inorganic entities (2-ethylaniline, $\mathrm{P}_{6} \mathrm{O}_{18}$ and $\left.\mathrm{H}_{2} \mathrm{O}\right)$. The asymmetric unit of $\left[2-\mathrm{CH}_{3} \mathrm{CH}_{2}-\right.$ $\left.\mathrm{C}_{6} \mathrm{H}_{4} \mathrm{NH}_{3}\right]_{6} \mathrm{P}_{6} \mathrm{O}_{18} \cdot 4 \mathrm{H}_{2} \mathrm{O}$ contains a half of the anion, three organic cations and two water molecules crystallographically independent.

The atomic arrangement of the title compound is a typical organization in layers. These layers are built up from anions and water molecules that develop parallel to the bc planes at $x=1 / 2$ (Figure 2). Charge compensation of these layers is achieved by the incorporation of the protonated 2ethylanilinium cations in the interlayer spaces establishing $\mathrm{H}$-bonds via their ammonium groups with $\mathrm{P}_{6} \mathrm{O}_{18}$ ring and water molecules. Adjacent $\mathrm{P}_{6} \mathrm{O}_{18}$ groups are linked pairwise with $\mathrm{O} 11$ water molecules so as to form an infinite chain spreading along the $\mathrm{b}$ direction. On the other hand, $\mathrm{O} 10$ water molecules link these infinite chains to give rise to infinite layers. Each cyclohexaphosphate group is connected to its adjacent neighbours by eight water molecules through $\mathrm{O}-\mathrm{H} \cdots \mathrm{O}$ hydrogen bonds. Inside such a structure, the complete cyclohexaphosphate anion is generated by inversion symmetry located at $(1 / 2,1 / 2,0)$ and $(1 / 2,0,1 / 2)$. So, it is built up by only three independent tetrahedral, $\mathrm{P}(1) \mathrm{O}_{4}$, $\mathrm{P}(2) \mathrm{O}_{4}$, and $\mathrm{P}(3) \mathrm{O}_{4}$. The geometry of this ring (Table 2) does not differ from the other known cyclohexaphosphates. The $\mathrm{P}-\mathrm{O}$ distances range in $(1.467(3)-1.610(3) \AA)$ and the $\mathrm{O}-$ $\mathrm{P}-\mathrm{O}$ bond angles in $\left(99.56(15)-120.34(15)^{\circ}\right)$. It is the same for the P-P distances ranging from 2.897 (1) to 2.940 (1) $\AA$, which are comparable to values generally measured [7-9].

The calculated average values of the distortion indices [10] corresponding to the different angles and distances in the $\mathrm{PO}_{4}$ tetrahedra $(\mathrm{DI}(\mathrm{OPO})=0.041, \mathrm{DI}(\mathrm{PO})=0.041$; and $\mathrm{DI}(\mathrm{OO})=0.012)$, show a pronounced distortion of the 


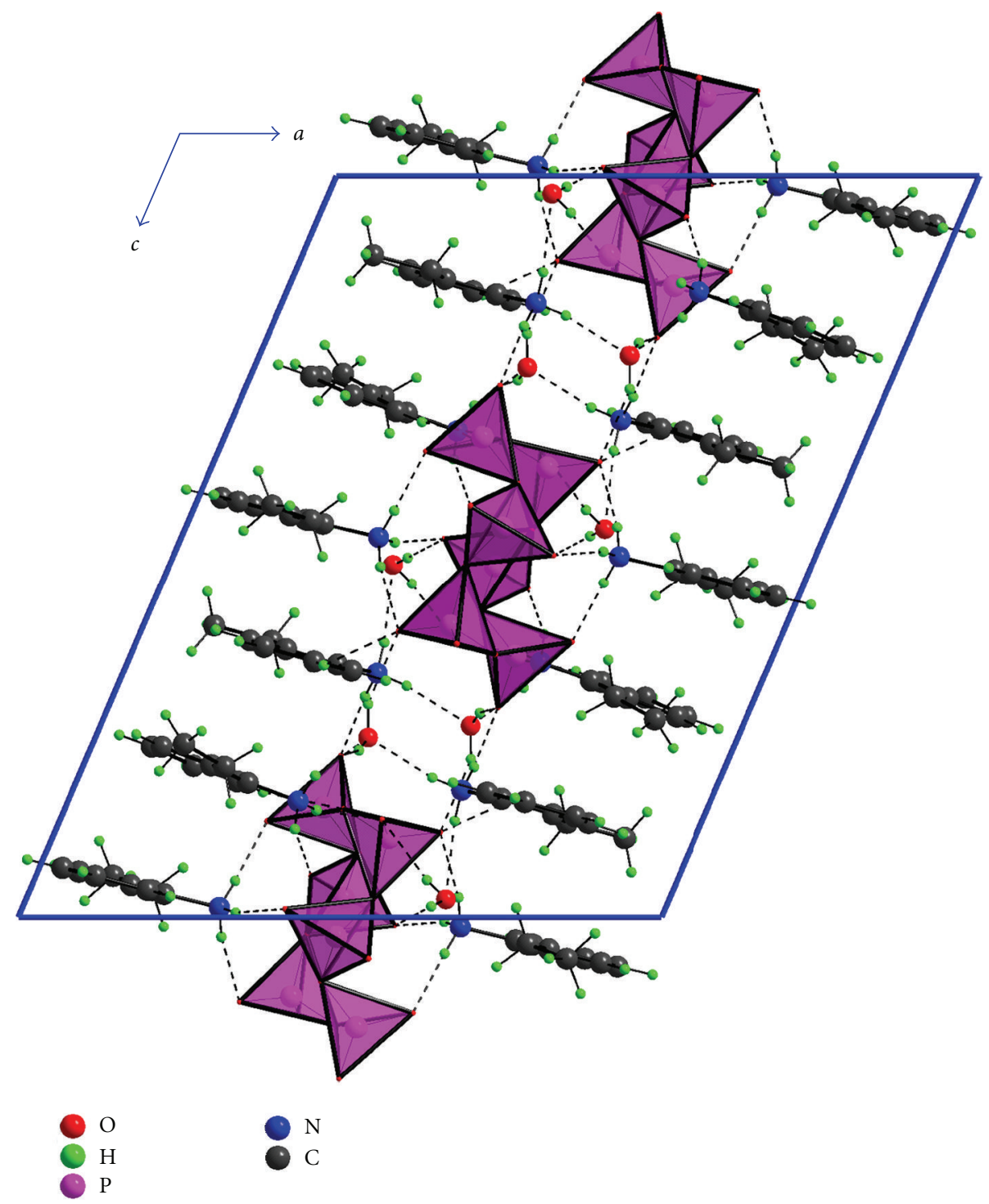

FIGURE 2: The atomic arrangement of $\left[2-\mathrm{CH}_{3} \mathrm{CH}_{2} \mathrm{C}_{6} \mathrm{H}_{4} \mathrm{NH}_{3}\right]_{6} \mathrm{P}_{6} \mathrm{O}_{18} \cdot 4 \mathrm{H}_{2} \mathrm{O}$ in projection along the $b$-axis. The phosphoric groups are given in tetrahedral representation. The other atoms are indicated by their symbols. Intermolecular H-bonds are denoted by dotted lines.

$\mathrm{PO}$ distances and $\mathrm{OPO}$ angles if compared to $\mathrm{OO}$ distances. So, the $\mathrm{PO}_{4}$ group can be considered as a rigid regular arrangement of oxygen atoms, with the phosphorus atom slightly displaced from the tetrahedron gravity centre.

Three independent 2-ethylanilinium cations are identified in the title compound. Interatomic bond lengths and angles of these groups are as expected $[11,12]$. The aromatic rings are planar with an average deviation of $0.000349 \AA$ and form dihedral angles of $2.56^{\circ}, 8.50^{\circ}$ and $8.59^{\circ}$ between them. The interplanar distance between nearby phenyl rings is in the vicinity of $3.972 \AA$, which is slightly longer than $3.80 \AA$ for the $\pi-\pi$ interaction [13].

The 2-ethylanilinium cations occupy the interlayer spaces and establish with the anionic framework $\mathrm{N}-\mathrm{H}$. . O hydrogen bonds. The $\mathrm{N}(1) \mathrm{H}_{3}$ groups produce the internal $\mathrm{P}_{6} \mathrm{O}_{18}$ ring cohesion through hydrogen bonds involving external oxygen atom of each $\mathrm{PO}_{4}$ tetrahedron. The $\mathrm{N}(3) \mathrm{H}_{3}$ groups link two different rings so as to form infinite chain extending along the $\mathrm{b}$ direction at $z=1 / 2$. While the $\mathrm{N}(2) \mathrm{H}_{3}$ groups are bounded to two different water molecules and one ring situated at $z=0$ and so contribute to the layer cohesion of this compound. The organic groups are also interconnected through weak $\mathrm{C}-\mathrm{H} \cdots \mathrm{O}$ hydrogen bonds with the $\mathrm{C} \cdot \cdots \mathrm{O}$ separation of 3.281(6)-3.422(8) $\AA$. The $\mathrm{C}-\mathrm{H}$. . O bonds have already been evidenced by several authors in molecular crystals [14].

There are two crystallographically independent water molecules $\mathrm{O}(10)$ and $\mathrm{O}(11)$ in this atomic arrangement. They interconnect the cyclohexaphosphate rings and the organic groups by establishing the hydrogen bonds; thus 


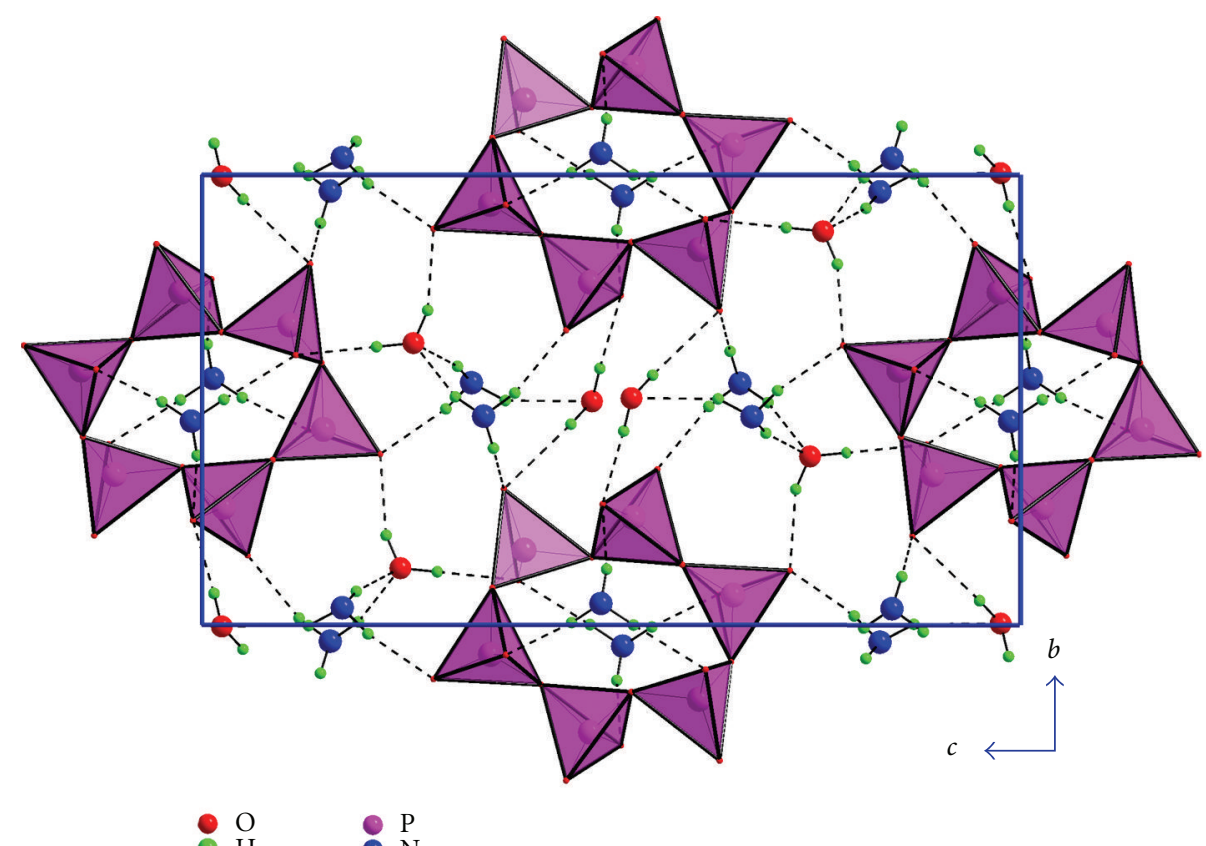

FIgURE 3: The atomic arrangement of $\left[2-\mathrm{CH}_{3} \mathrm{CH}_{2} \mathrm{C}_{6} \mathrm{H}_{4} \mathrm{NH}_{3}\right]_{6} \mathrm{P}_{6} \mathrm{O}_{18} \cdot 4 \mathrm{H}_{2} \mathrm{O}$ in projection along the $a$-axis. The phosphoric anions are given in tetrahedral representation. Organic groups are represented by the $\mathrm{NH}_{3}$ groups. Intermolecular $\mathrm{H}$-bonds are denoted by dotted lines.

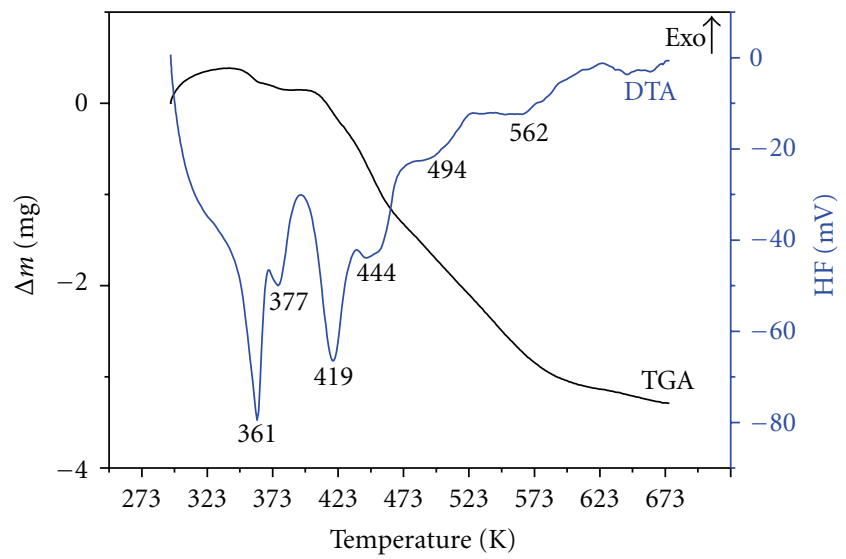

FIGURE 4: DTA and TGA thermograms of the title compound with increasing temperature.

the water molecules act as proton donors and acceptors while the protonated amine groups are exclusively acceptors (Figure 3, Table 3). The cohesion forces in this compound are assured by electrostatic interactions, van der Waals contacts and hydrogen bonds $(\mathrm{O}-\mathrm{H} \cdots \mathrm{O}, \mathrm{N}-\mathrm{H} \cdots \mathrm{O}$ and $\mathrm{C}-\mathrm{H} \cdots \mathrm{O}$ ).

3.2. Thermal Analysis. The two curves corresponding to DTA and TGA analysis carried out in an argon atmosphere in the temperature range [ $298 \mathrm{~K}-673 \mathrm{~K}$ ] are given in Figure 4 . The DTA curve shows that the cyclohexaphosphate undertakes

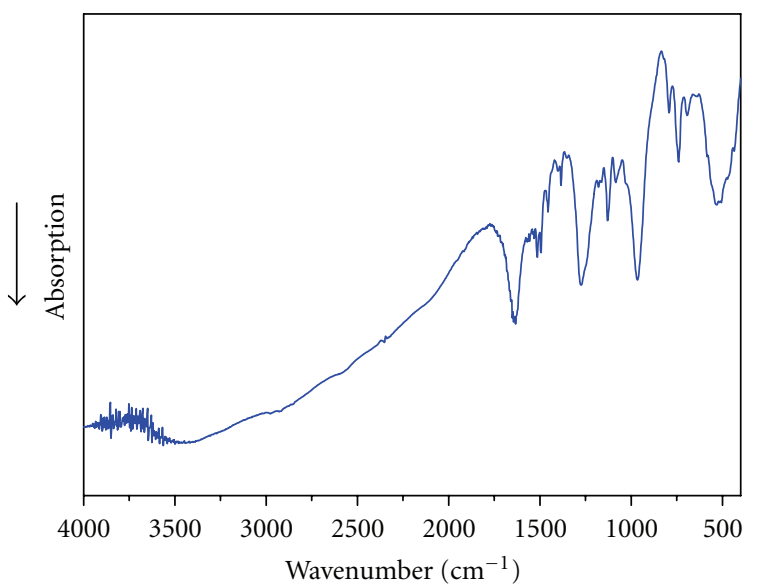

FIGURE 5: IR spectrum of $\left[2-\mathrm{CH}_{3} \mathrm{CH}_{2} \mathrm{C}_{6} \mathrm{H}_{4} \mathrm{NH}_{3}\right]_{6} \mathrm{P}_{6} \mathrm{O}_{18} \cdot 4 \mathrm{H}_{2} \mathrm{O}$.

a succession endothermic phenomenon. The first two peaks correspond to the dehydration, which occurs at about $361 \mathrm{~K}$, and $377 \mathrm{~K}$ are accompanied with a weight loss obviously observed in the TGA curve. From this latter, we deduce a departure of four water molecules (\% experimental: 5.59\%, calculated: $5.63 \%$ ). At about $419 \mathrm{~K}$, another endothermic peak appears, corresponding to the degradation of the 2ethylanilinium, accompanied with a significant weight loss clearly observed on the TGA curve. This degradation gives a viscous substance of polyphosphoric acids contaminated with a carbon black deposit. 
3.3. IR-Absorption Spectroscopy. The infrared absorption spectrum is reported in Figure 5. It exhibits

(i) broad bands between $3600-3300 \mathrm{~cm}^{-1}$ and 1600 $1370 \mathrm{~cm}^{-1}$ corresponding, respectively, to the stretching and bending modes of $\mathrm{NH}_{3}$. They are indicative of the presence of the 2-ethylaniline molecules in its protonated form [15]. The broadness of the IR bands is probably due to the existence of hydrogen bonds of varying strengths in the crystal;

(ii) various valency vibration bands whose positions, between 1350 and $660 \mathrm{~cm}^{-1}$, are characteristic of cyclohexaphosphate anion [16]. In this type of anions, the stretching vibrations $v_{\mathrm{as}}(\mathrm{OPO})^{-}$and $v_{\mathrm{s}}(\mathrm{OPO})^{-}$ are observed, respectively, between $1350-1180 \mathrm{~cm}^{-1}$ and $1180-1060 \mathrm{~cm}^{-1}$, while the stretching vibration bands originating from both asymmetric $v_{\mathrm{as}}(\mathrm{POP})$ and symmetric $\nu_{s}(\mathrm{POP})$ modes are, respectively, observed in the range (1060-960) and (850-660) $\mathrm{cm}^{-1}$ region, and those below $660 \mathrm{~cm}^{-1}$ correspond to bending, translation, and rotation of the $\mathrm{P}_{6} \mathrm{O}_{18}$ ring.

\section{Conclusions}

[2- $\left.\mathrm{CH}_{3} \mathrm{CH}_{2} \mathrm{C}_{6} \mathrm{H}_{4} \mathrm{NH}_{3}\right]_{6} \mathrm{P}_{6} \mathrm{O}_{18} \cdot 4 \mathrm{H}_{2} \mathrm{O}$ is prepared as single crystals at room temperature and characterized by X-ray diffraction, thermal behaviour, and IR spectroscopic. Crystal structure of this compound was found to be built by infinite layers of $\mathrm{P}_{6} \mathrm{O}_{18}^{6-}$ and water molecules parallel to the bc planes around $x=1 / 2$. Between these layers, the 2-ethylanilinium cations are located. Both inorganic and organic components perform different interactions (electrostatic, $\mathrm{H}$-bonds and van der Waals) to stabilize the three-dimensional network. When heated, the compound loses the four coordinated water molecules at $361 \mathrm{~K}$ and $377 \mathrm{~K}$. By heating further, the compound exhibits a degradation of the organic entities confirmed by the obtained carbon black residue at the end of the experiment.

\section{References}

[1] D. Gani and J. Wilkie, "Stereochemical, mechanistic, and structural features of enzymecatalysed phosphate monoester hydrolyses," Chemical Society Reviews, vol. 24, no. 1, pp. 5563, 1995.

[2] I. V. Tananaev, H. Grünze, and N. N. Chudinova, "Osnovnye napravleniya i rezul'taty issledovanii $\mathrm{v}$ oblasti khimii kondensirovannykh fosfatov," Izvestiya Akademii Nauk SSSR, Neorganicheskie Materialy, vol. 20, no. 6, pp. 887-900, 1984.

[3] J. W. R. Masse, M. Bagieu-Beucher, J. Pecaut, J. P. Lévy, and J. Zyss, "Design of organic-inorganic polar crystals for quadratic nonlinear optics," Nonlinear Optics, vol. 5, pp. 413-423, 1993.

[4] U. Schülke and R. Kayser, "Zur thermischen dehydratisierung von lithiumdihydrogenphosphat, hydrogendiphosphat und cyclophosphat-hydraten," Zeitschrift für Anorganische und Allgemeine Chemie, vol. 531, no. 12, pp. 167-175, 1985.

[5] G. M. Sheldrick, "A short history of SHELX," Acta Crystallographica, vol. 64, pp. 112-122, 2008.

[6] G. Mountjoy, "WinGX suite for single crystal small molecule crystallography," Journal of Applied Crystallography, vol. 32, pp. 837-838, 1999.
[7] H. Marouani, M. Rzaigui, and M. Bagieu-Beucher, "Synthesis and crystal structure of $\left(1,6-\mathrm{NH}_{3} \mathrm{C}_{6} \mathrm{H}_{12} \mathrm{NH}_{3}\right){ }_{2}(1-$ $\left.\mathrm{NH}_{3} \mathrm{C}_{10} \mathrm{H}_{7}\right)_{2} \mathrm{P}_{6} \mathrm{O}_{18} .2 \mathrm{H}_{2} \mathrm{O}$," European Journal of Solid State and Inorganic Chemistry, vol. 35, no. 6-7, pp. 459-471, 1998.

[8] H. Marouani and M. Rzaigui, "Synthesis and crystal structure of $\left(\left(\mathrm{NH}_{3} \mathrm{CH}_{2} \mathrm{CH}_{2}\right)_{3} \mathrm{~N}\right)_{2} \mathrm{P}_{6} \mathrm{O}_{18} \cdot 6 \mathrm{H}_{2} \mathrm{O}$," Solid State Sciences, vol. 1, no. 6, pp. 395-408, 1999.

[9] H. Marouani, M. Rzaigui, and M. Bagieu-Beucher, "(m$\left.\mathrm{CH}_{3} \mathrm{C}_{6} \mathrm{H}_{4} \mathrm{NH}_{3}\right)_{6} \mathrm{P}_{6} \mathrm{O}_{18}$," Acta Crystallographica, vol. 56, no. 3, pp. 356-357, 2000.

[10] W. H. Baur, "The geometry of polyhedral distortions. Predictive relationships for the phosphate group," Acta Crystallographica, vol. 30, pp. 1195-1215, 1974.

[11] S. Akriche and M. Rzaigui, "Crystal growth and structure of $\left(2-\mathrm{C}_{2} \mathrm{H}_{5} \mathrm{C}_{6} \mathrm{H}_{4} \quad \mathrm{NH}_{3}\right)_{2} \mathrm{H}_{2} \mathrm{P}_{2} \mathrm{O}_{7}$," Materials Research Bulletin, vol. 36, no. 1-2, pp. 375-382, 2001.

[12] W. Smirani, C. B. Nasr, and M. Rzaigui, "Synthesis and crystal structure of a new o-ethylphenylammonium triphosphate $\left[2-\mathrm{C}_{2} \mathrm{H}_{5} \mathrm{C}_{6} \mathrm{H}_{4} \mathrm{NH}_{3}\right]_{3} \mathrm{H}_{2} \mathrm{P}_{3} \mathrm{O}_{10}$," Materials Research Bulletin, vol. 39, no. 7-8, pp. 1103-1111, 2004.

[13] C. Janiak, "A critical account on n-n stacking in metal complexes with aromatic nitrogen-containing ligands," Journal of the Chemical Society, Dalton Transactions, no. 21, pp. 38853896, 2000.

[14] T. Steiner and W. Saenger, "Lengthening of the covalent O$\mathrm{H}$ bond in $\mathrm{O}-\mathrm{H}$...O hydrogen bonds re-examined from lowtemperature neutron diffraction data of organic compounds," Acta Crystallographica, vol. 50, pp. 348-357, 1994.

[15] D. Dolphin and A. E. Wick, Tabulation of Infrared Spectra Data, John Wiley \& Sons, New York, NY, USA, 1977.

[16] A. N. Lazarev, Vibrational Spectra and Structure of Silicates, Consultants Bureau, New York, NY, USA, 1972, Translated from the Russian by G. D. Archard. Translations editor Victor C. Farmer. 

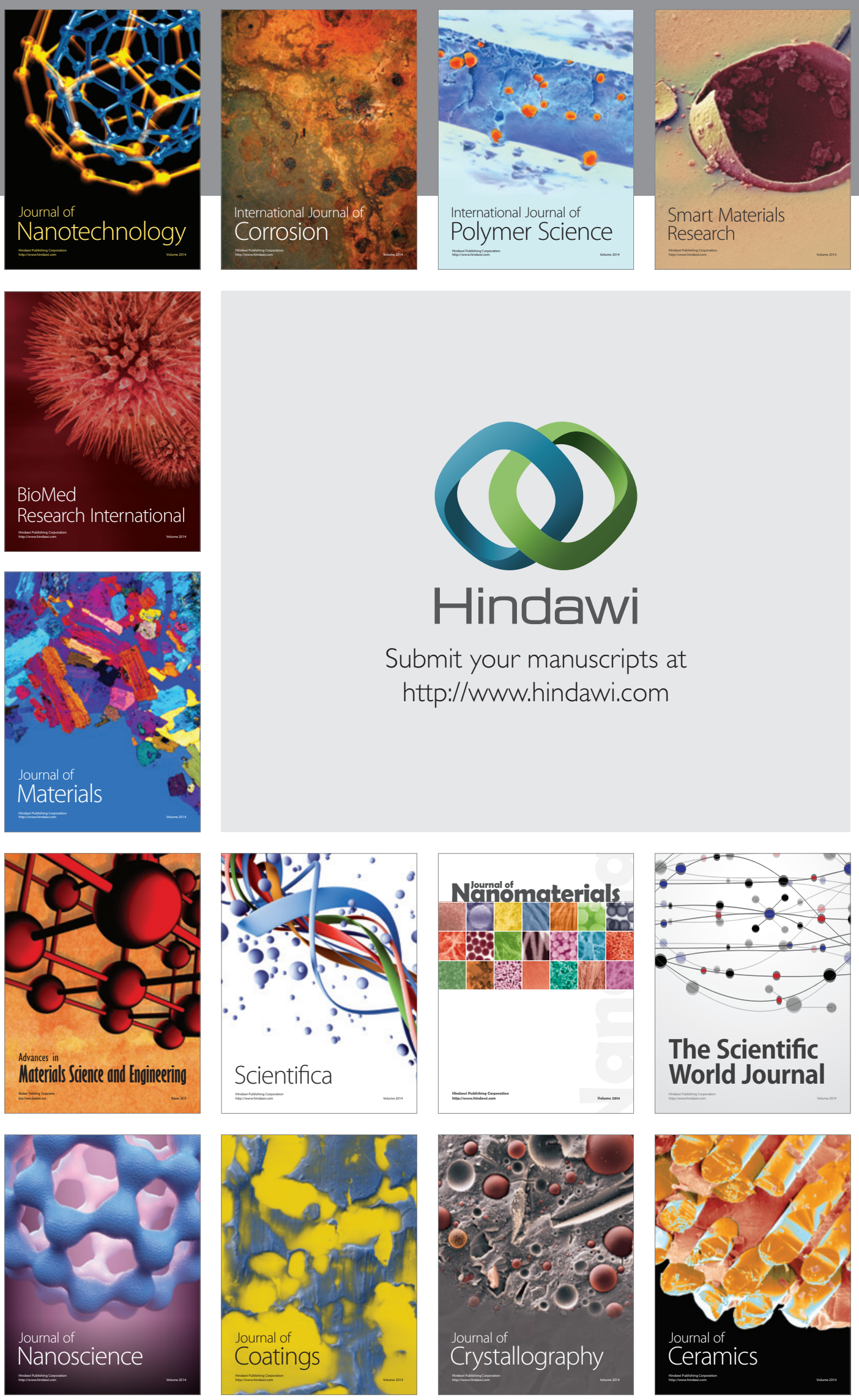

The Scientific World Journal

Submit your manuscripts at

http://www.hindawi.com

\section{World Journal}

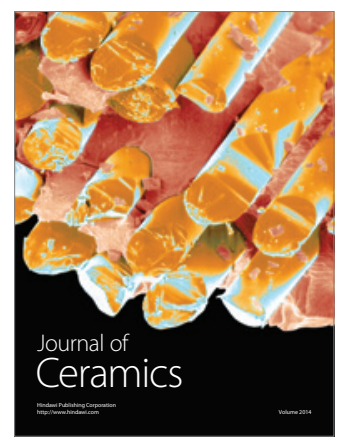

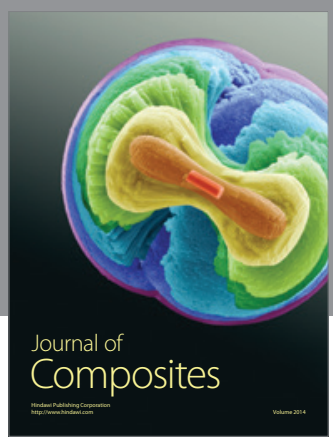
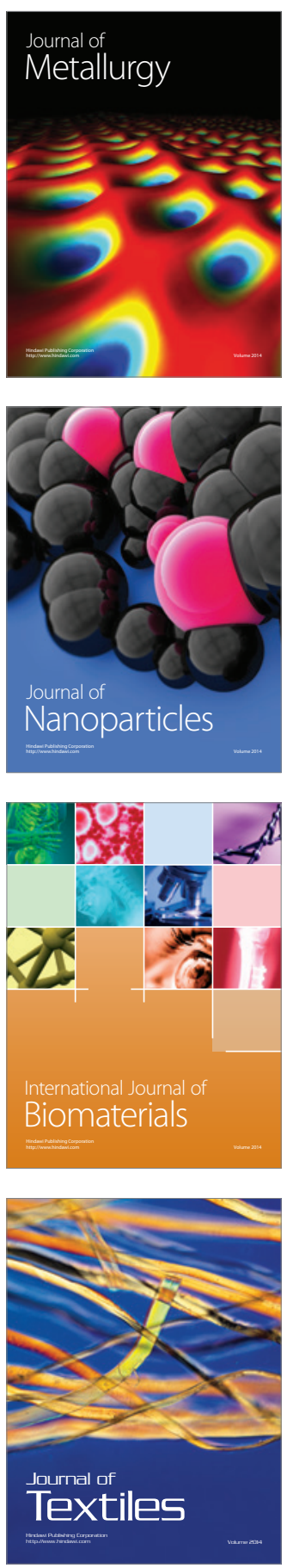